\title{
Organic carbon and microbial food web assemblages in an oligotrophic alpine lake
}

\author{
Cristiana CALLIERI* and Roberto BERTONI \\ C.N.R. - Istituto Italiano di Idrobiologia, Largo Tonolli 50, 28922 Verbania-Pallanza, Italy \\ *e-mail corresponding author: c.callieri@iii.to.cnr.it
}

\begin{abstract}
Picoplankton, both autotrophic (APP) and heterotrophic (HPP), ciliates and heterotrophic nanoflagellates (HNF) were counted and their biovolume measured monthly over a 3 year period in Lake Paione Superiore (LPS), a high mountain lake in the Italian alpine region. Analyses of organic carbon, particulate and dissolved, were performed at the same time. APP were negligible and picocyanobacteria almost absent. HPP showed seasonal variations, with low numbers in winter/spring and maxima of nearly $10^{6}$ cell $\mathrm{ml}^{-1}$ in August/September, corresponding to $60 \mu \mathrm{g} \mathrm{Cl} l^{-1}$. Free-living, non-pigmented flagellates showed a density range from $10^{4} \mathrm{l}^{-1}$ to $10^{6} \mathrm{l}^{-1}$ with a prevalence of cells $<3 \mu \mathrm{m}$. Their carbon ranged between $0.1-9 \mu \mathrm{g} \mathrm{Cl} l^{-1}$. Ciliate numbers ranged from 0.02 to $1110^{3} \mathrm{l}^{-1}$. For much of the year different species of Urotricha were found. Conversely, Strombidium appeared during the ice-free period and Halteria grandinella under the ice, indicating a strict dependence on temperature. Carbon in the microbial loop of LPS (near the bottom) was mainly confined to bacteria (73\%), with $20 \%$ in HNF and only $7 \%$ in ciliates. Total organic carbon (TOC) concentration, measured after the removal of net plankton, ranged from 0.26 to $1.77 \mathrm{mgCl}^{-1}$ with a prevalence of the dissolved form (87\% av.). The average particulate organic carbon (POC) concentration was $0.24 \mathrm{mgCl} l^{-1}$. All the components of the microbial loop showed a decline under the ice-cover. Bacterial carbon concentration was three times lower under the ice than in the ice-free season (7.9$24.4 \mu \mathrm{gCl} l^{-1}$, respectively); protozoa carbon too declined under the ice-cover (3.1-5.8 $\mu \mathrm{gC} l^{1}$ for $\mathrm{HNF}$ and $0.4-1.7 \mu \mathrm{gC} l^{-1}$ for ciliates in the ice-cover and ice-free periods, respectively). The drop in the microbial-loop carbon occurring in late summer may be related to the presence of a Daphnia population peak. At that moment, the structure of the microbial loop is transformed by a top-down control of Daphnia.
\end{abstract}

Key words: microbial loop, high mountain lake, TOC, Lake Paione Superiore

\section{INTRODUCTION}

Since the 50s, Alpine lakes have been looked on as special "lab-like" systems in which to study the biology and ecology of plankton in extreme conditions of light and temperature (Tonolli 1949; Tonolli 1954; Tilzer 1973). The organisms living there acquired adaptation mechanisms to exploit to the maximum the few ice-free months and to survive during the long ice-cover period (Tilzer \& Schwarz 1976). Conventional limnological studies (Giussani et al. 1986; Mosello et al. 1993) on zooplankton (de Bernardi et al. 1983; Cammarano \& Manca 1997), phytoplankton (Pechlaner 1971; Capblancq \& Laville 1983; Pugnetti \& Bettinetti 1995), hydrochemistry and paleolimnology (Mosello 1984; Psenner 1989; Guilizzoni et al. 1996) have been performed up to now in various high mountain lakes in the Alps. In the 80s the process of acidification, which occurred in many areas of northern Europe, also affected some lakes in the Italian Alps (Mosello 1986). International Projects like AL:PE "Acidification of mountain Lakes: Palaeolimnology and Ecology" (Wathne 1992) and more recently MOLAR "MOuntain LAkes Research" (Patrick et al. 1998) supported studies on some lakes which were sensitive to environmental changes, to measure their dynamic response. With the purpose of constructing a seasonal model of carbon flux in the pelagic zone of acidified mountain lakes, the study of microbial food web assemblages has been proposed as a fundamental support to classical limnological studies. Microbial components must in fact be incorporated into any model on the pelagic food web, as their key role is now widely accepted (Azam et al. 1983). In this context a research was planned to study the microbial loop and organic carbon in various acidified lakes in Europe. Lake Paione Superiore (LPS), a small glacial lake in the Central Italian Alps, was selected as one of these experimental sites. Our study on LPS was mainly concerned with the seasonal dynamics of picoplankton, both autotrophic (APP) and heterotrophic (HPP), ciliates and heterotrophic nanoflagellates (HNF) and both dissolved and particulate organic carbon.

\section{MATERIAL AND METHODS}

Organic carbon and microbial assemblages were studied from July 1996 to December 1998 in Lake Paione Superiore (LPS), an oligotrophic glacial lake at an altitude of $2269 \mathrm{~m}$ in the Bognanco Valley (Pennine Alps, Italy) (Bianchini 1952). The lake area is 0.014 $\mathrm{km}^{2}$ and its maximum depth $11.7 \mathrm{~m}$. Chemical studies (Mosello et al. 1993) have shown that LPS is poorly buffered by carbonates, with pH 5.6 (1993 average), due mainly to atmospheric deposition. In 1997 and $1998 \mathrm{pH}$ increased slightly to 5.7 under the ice and 6.0 in the ice 
free periods. The lake is ice-covered for around 8 months. In the studied period, there was a typical inverse thermal stratification under the ice with temperatures below $3{ }^{\circ} \mathrm{C}$ in the upper $9 \mathrm{~m}$ in May/June. Stratification occurred in August with a thermocline at $9 \mathrm{~m}$ in 1997 and $6 \mathrm{~m}$ in 1998; the maximum temperature was $14{ }^{\circ} \mathrm{C}$. Full details of the main geographic, morphometric, chemical, physical and biological characteristics of Lake Paione Superiore, together with a description of the sampling station, can be found in Pugnetti \& Bettinetti (1995) and Cammarano \& Manca (1997). Updated information regarding the evolution of the chemical variables can be found in this issue (The MOLAR Water Chemistry Group 1999).

A total of 24 samplings were performed at the site of maximum depth, also during the ice-cover period. Two sampling depths were chosen: one meter under the surface in summer (under the ice-water interface in winter) (SUR) and one meter above the bottom (BOT). For fixing and counting bacteria or HPP (heterotrophic picoplankton), APP (autotrophic picoplankton), HNF (heterotrophic nanoflagellate), and ciliates the protocols by et al. (1999, this issue) were used. All the organisms were measured by image analysis and the biovolumes converted to carbon using convenient conversion factors (Straškrabová et al. 1999, this issue). For ciliate taxonomy we followed the directions of the MOLAR working group, determining the genus and in some case the species (M. Macek, pers. com.). The exception was the staining of bacteria, which was done using Acridine Orange instead of DAPI and the use of Anopore filters instead of Nucleopore membranes of the same porosity $(0.2 \mu \mathrm{m}$ pore size $)$.
Shimadzu). At least 10 analyses per sample were made and the CV\% was always $\sim 1 \%$.

\section{RESULTS}

\subsection{Organic Carbon}

In LPS, the total organic carbon (TOC) concentration measured after the removal of net plankton ranged from 0.26 to $1.77 \mathrm{mg} \mathrm{C} \mathrm{l}^{-1}$, (average: $1.02 \pm 0.39 \mathrm{mg} \mathrm{C}$ $\mathrm{l}^{-1}$ ). The TOC data sets of the Molar lakes (Straškrabová, pers. comm.) show that in about $50 \%$ of these water bodies TOC concentrations $<1 \mathrm{mg} \mathrm{C}^{-1}$ are found. The average concentration of dissolved organic carbon (DOC) was $0.89 \pm 0.39 \mathrm{mg} \mathrm{C}^{-1}$, with mean values of 0.78 and $0.99 \mathrm{mg} \mathrm{C}^{-1}$ at SUR and BOT, respectively. The DOC concentrations of LPS were compared with those of other high altitude lakes (Tab. 1). LPS appears not to be an exception among these environments. It must be emphasized that a high DOC concentration was only measured in the permanently meromictic Lake Cadagno, which receives a supply of inorganic nutrients from underwater springs and hosts a large autotrophic bacteria population in the anoxic chemocline.

The average concentration of the particulate organic fraction (POC) was 0.21 and $0.27 \mathrm{mgC} \mathrm{l}^{-1}$ at SUR and BOT, respectively; these concentrations represent 21 and $26 \%$ of TOC. Nevertheless, the slight differences between SUR and BOT are not statistically significant.

In LPS most of the organic carbon is dissolved (av. $87 \%$ ) and $78 \%$ of the particulate fraction is detritus. The contribution of microscopically recognizable organisms of the microbial loop to the total organic carbon pool of the lake is $3 \%$, considering the mean of the three years,

Tab. 1. Average dissolved organic carbon (DOC) concentration of LPS compared with that found in other high altitude lakes.

\begin{tabular}{lcccl}
\hline & m a.s.l. & $\mathrm{mgC}^{-1}$ & s.d. & \\
\hline L. Paione Superiore & 2269 & 0.89 & 0.39 & this study \\
Lake Kastel & 2210 & 0.46 & 0.13 & Bertoni unpubl. data \\
Lake Cadagno (CH) & 1923 & 2.35 & 0.95 & Bertoni et al. 1998 \\
52 lakes in Austrian Alps & $2600-2800$ & 0.53 & 0.18 & Sommaruga-Wögrath et al. 1998 \\
& $2000-2200$ & 1.3 & 0.8 & \\
L. Piramide Inf. (Himalayas) & 5050 & 0.65 & 0.23 & Ruggiu et al. 1998 \\
L. Piramide Sup. (Himalayas) & 5050 & 0.41 & 0.09 & \\
Sky Pond (Rocky $\mathrm{M}^{\mathrm{nt}}$ ) & & 0.37 & & McKnight et al. 1997 \\
\hline
\end{tabular}

For the organic carbon analyses, after filtering the water samples through a $126 \mu \mathrm{m}$ mesh plankton net, the POC was concentrated by filtration on glass fiber filters (Whatman GF/C, $16 \mathrm{~mm}$ diameter) previously combusted at $500{ }^{\circ} \mathrm{C}$ for three hours. The filters were then dried at $60{ }^{\circ} \mathrm{C}$ for three hours. Duplicate POC analyses were carried out with a CHN analyser (ANA 1500, Carlo Erba) using the technique described by Bertoni (1978). The coefficient of variation (CV\%) for replicate estimations was $<2 \%$. The TOC was determined on 126 $\mu \mathrm{m}$ pre-filtered samples using a TOC Analyser (5000A, which never exceeds $25 \%$. The seasonal pattern of TOC (Fig. 1), largely due to DOC concentration changes, might be the result of external input from the catchment and of active processes of DOC production-consumption. The ice-melt produces an increase of TOC concentration which subsequently declines in July/August (more evidently in SUR). In September the release of DOC during macrozooplankton feeding might be a source which causes the obesrved increase. In late summer a zooplankton community dominated by Daphnia was observed (Manca \& Comoli 1999, this issue). 
This trend is not synchronous at SUR and BOT. Large TOC concentration gradients from the two layers appear occasionally with and without ice cover, although there is not a statistically significant TOC concentration difference between the two depths.

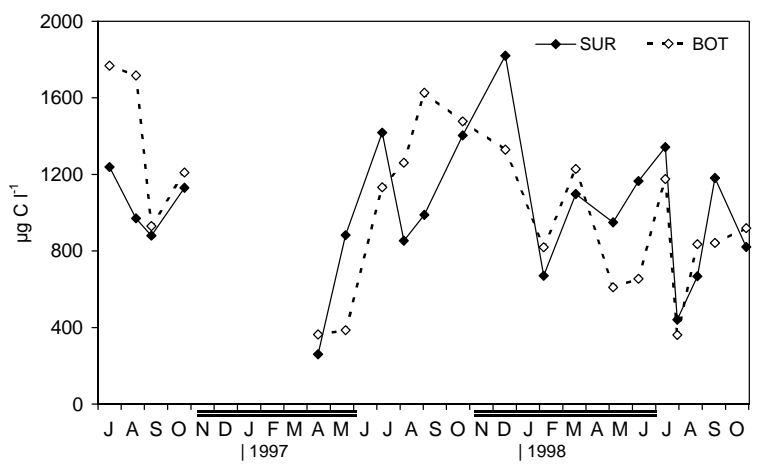

Fig. 1. Seasonal trend of total organic carbon (TOC: $\mu \mathrm{g} \mathrm{C}^{-1}$ ) concentration measured one meter below surface (SUR) and one meter above bottom (BOT) in LPS.

\subsection{Picoplankton (APP and HPP)}

The cells in the size range from 0.2 to $2 \mu \mathrm{m}$ which are referred to as picoplankton (Stockner \& Antia 1986) were in this study counted and measured differentiating the autotrophic fraction (APP) from the heterotrophic fraction (HPP). This separation, which is now routinely performed thanks to the natural autofluorescence of APP and by the use of fluorocromes for HPP staining, was particularly important for the LPS samples. APP were in fact quite rare and, when found, they were composed mainly of eukaryotic cells; picocyanobacteria were almost absent. The numbers counted were so low (Fig. 2) as to let us consider this small fraction of the autotrophic population negligible. The mean abundance during the three years was 50 and 26 cell ml $^{-1}$ at SUR and BOT respectively. Comparable low carbon values were calculated from the biovolumes, with a maximum of $\sim 0.1 \mu \mathrm{g} \mathrm{Cl}^{-1}$ (Fig. 2). Synechococcus and Cyanobium (sensu Komárek 1996) were rarely found and a coccoid form $>2 \mu \mathrm{m}$ was sometimes observed (probably Chroococcus). Colonial forms like Merismopedia tenuissima, found in acidic-eutrophic Swedish lakes, (Blomqvist 1996) were similarly never encountered.

The heterotrophic component of picoplankton (HPP) was, on the other hand, the most important carbon reserve in the microbial loop of Lake Paione Superiore. Their percentages were $79 \%$ and $73 \%$ of the mean total carbon in the microbial loop (APP, HPP, HNF, ciliates) at SUR and BOT, respectively. Patterns of bacterial abundance were similar to those of biomass, expressed as carbon, for many of the months during the three years (Fig. 2). The lowest densities $\left(0.1 \times 10^{6} \mathrm{ml}^{-1}\right)$ were typically found in spring under the ice-cover and corresponded to low carbon concentrations (around $5 \mu \mathrm{g} \mathrm{C}$
$1^{-1}$ ). In 1997 and 1998 the HPP increased in July-August, both as numbers (reaching nearly $1 \times 10^{6} \mathrm{l}^{-1}$ ) and as biomass. The presence of large rods and filamentous forms resulted in high carbon values (63 and $58 \mu \mathrm{g} \mathrm{C}^{-1}$ in August 1997).

\subsection{Heterotrophic nanoflagellates (HNF)}

Free-living, non pigmented flagellates showed a density range from $4 \times 10^{4} 1^{-1}$ to $4 \times 10^{6} 1^{-1}$. An exceptionally high number of $>3 \mu \mathrm{m}$ cells was reached in July 1998 at BOT $\left(17 \times 10^{6} \mathrm{l}^{-1}\right)$. In the ice-free period of 96 both the number and the carbon were low, and there was a progressive increase of numbers until 1998. From July 1997 to October 1998 the counting was performed differentiating between small cells $(<3 \mu \mathrm{m})$ and large cells ( $>3 \mu \mathrm{m}$ and never exceeding $10 \mu \mathrm{m}$ ); the results show (Fig. 3, upper panel) that under the ice-cover low numbers in both size classes are followed by an increase in size diversity and numbers during the ice-free periods. The smaller cells could be identified as Spumella-like chrysomonads (Patterson \& Larsen 1991). These cells are more numerous than the larger ones and decrease in August/ September. Carbon data under the ice reflect the prevalence of larger over small HNF, so that in December and February the carbon can be as high as $9 \mu \mathrm{g}$ $\mathrm{C}^{-1}$ due to the large cells (Fig. 3, lower panel). It must be noted that in counting the $>3 \mu \mathrm{m}$ cells some errors may have been made, as the fluorescence of the mixotrophs was so weak that they could appear like true heterotrophs. In late summer 1998, near the bottom, the HNF carbon dropped from 43 to $3 \mu \mathrm{g} \mathrm{C}^{-1}$ in 26 days. The HNF carbon declined at the same time as the occurrence of Daphnia, thus indicating a possible top-down control by this cladoceran of an important component of the microbial loop.

\subsection{Ciliates}

Thirteen genera or species of ciliates were identified in LPS (Tab. 2). Prostomatids were present for much of the year (Fig. 4) with at least 3 different species: Urotricha furcata, $U$. agilis and another not well-identified species (probably U. globosa). Their presence (range 16-8980 ind $\mathrm{l}^{-1}$ ) was observed at both depths and also under the ice. The peak of abundance was reached in August 97 near the bottom. On the same date but in SUR, Holophrya sp. had a simultaneous peak. The presence of two oligotrichs, Strombidium sp. and Pelagohalteria characterized the summer period, whereas Halteria grandinella was mainly found under the icecover (ranges: Strombidium 8-960 ind $1^{-1}$, Halteria 81950 ind $1^{-1}$ ). Scuticociliates with Cinetochilum margaritaceum and Cyclidium sp. had their maximum under the ice (213 ind $1^{-1}$, near the bottom) and in summer (213 ind $1^{-1}$, August 98). In July 98 the presence of cysts (presumably of Halteria) must be noted. 

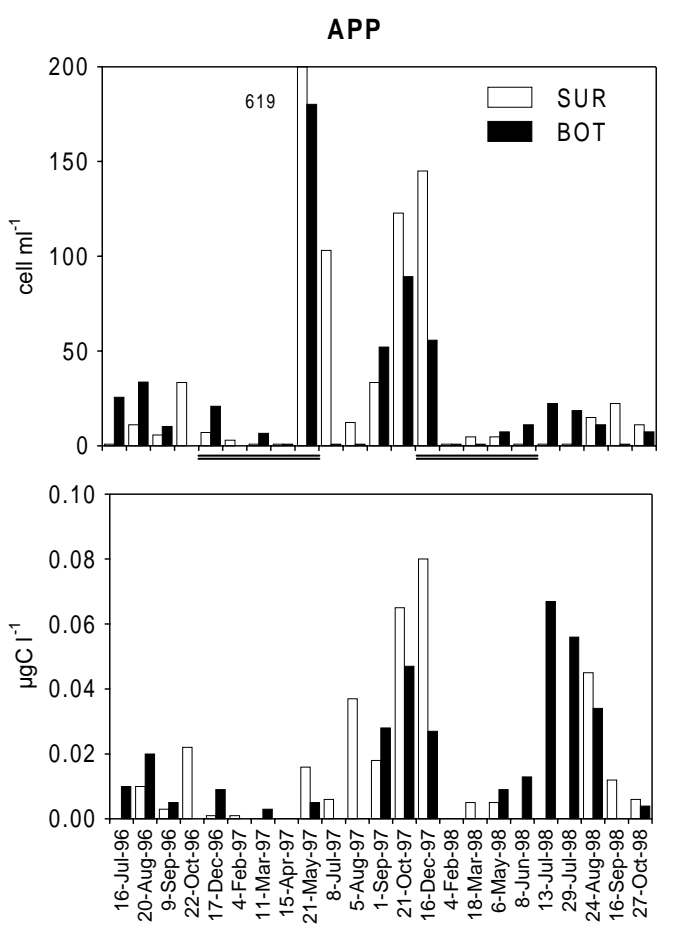

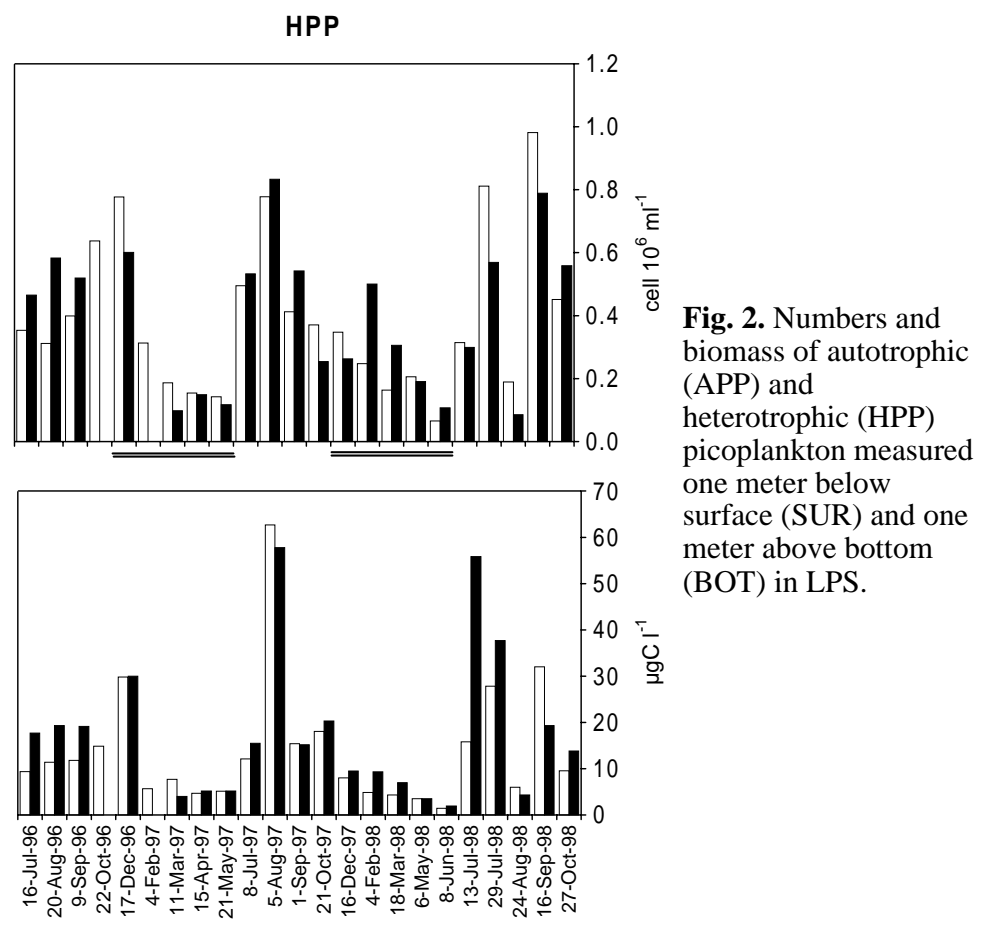

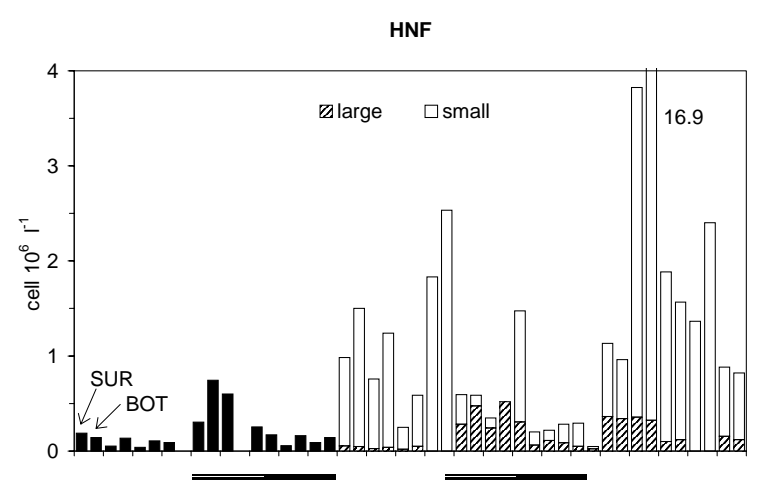

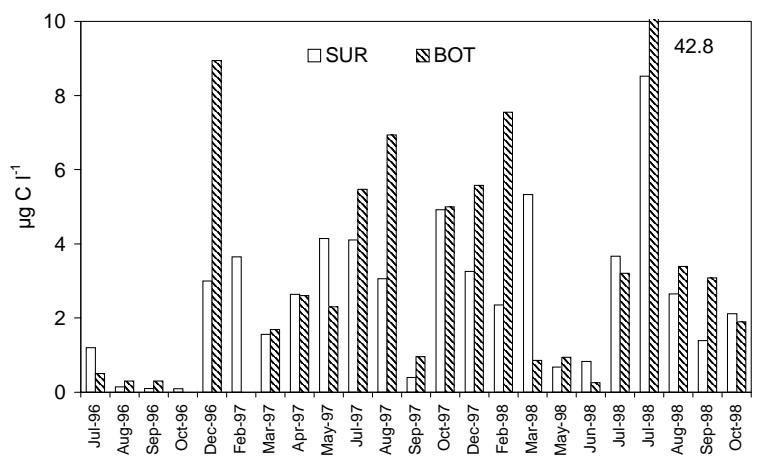

Fig. 3. Numbers (upper panel: cell $\times 10^{6} 1^{-1}$ ) and biomass (lower panel: $\mu \mathrm{g} \mathrm{C}^{-1}$ ) of heterotrophic nanoflagellates (HNF) measured one meter below surface (SUR) and one meter above bottom (BOT) in LPS. In upper panel the SUR and BOT bars are in sequence in each month; starting from July 97 the contribution of large and small cells is also indicated.
The biomass of planktonic ciliates varied temporally during the three years with a more pronounced pattern

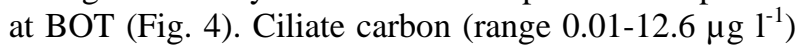
was dominated by oligotrichs and prostomatids; it increased in July/August, rapidly declined in September and remained fairly constant and low till the new ice break. At SUR in January and February an increase in carbon was mainly due to Halteria grandinella $(1 \mu \mathrm{g} \mathrm{C}$ $\left.1^{-1}\right)$.

\subsection{Ice-cover and ice-free periods}

The presence or the absence of the ice-cover in LPS seems to trigger generalized changes in the microbial loop and related variables. The overall organic carbon content of the organisms was, during the ice-cover period, about $50 \%$ less than in summer (from 28 to $11 \mu \mathrm{g}$ $\mathrm{C}^{-1}$, considering all the data from 1996 to 1998). The data from the SUR and BOT samples were pooled together, as there was not a statistically significant difference between the carbon in the microbial food web at the two depths. The results showed that the structure of the microbial loop was different in the ice-cover and ice-free periods as the relative importance of HNF increased compared with that of bacteria, which yet remained the main carbon compartment (Tab. 3). On average the TOC decreased by $20 \%$ during the ice-cover, although there were large fluctuations. The relation of the variations in TOC with the presence of HPP was weak, since bacterial biomass under the ice did not increase with increasing TOC concentration (Fig. 5). With the increase of temperature during the ice-free period, 

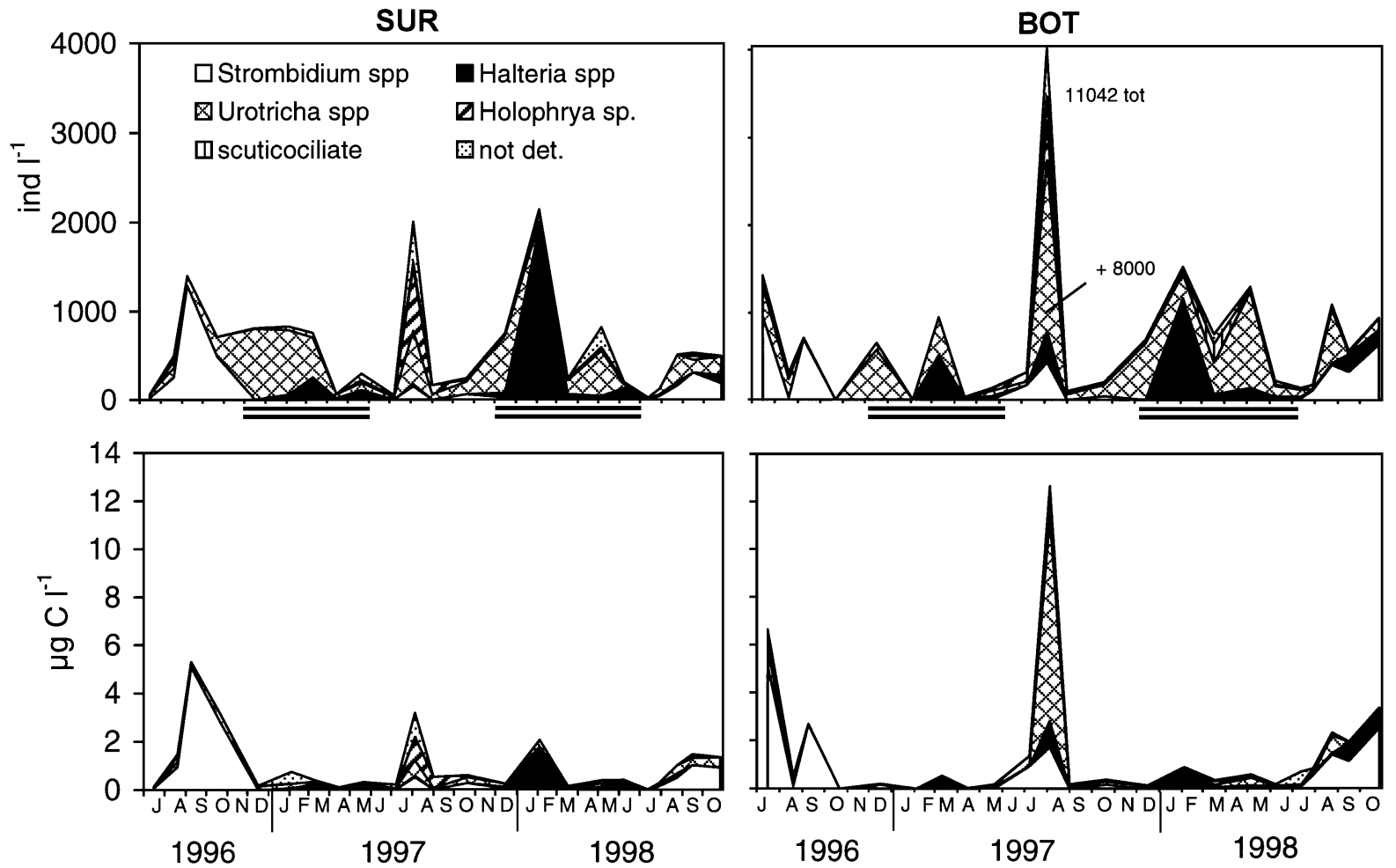

Fig. 4. Abundance (ind $\mathrm{l}^{-1}$ ) and biomass $\left(\mu \mathrm{gC} 1^{-1}\right)$ of species in the ciliate community one meter below surface (SUR: left) and one meter above bottom (BOT: right) in LPS.

higher bacterial biomass was often found; on some occasions, bacterial carbon values were from two to five times higher than during winter, with substrate concentration as high as under the ice-cover (Fig. 5). As these occurrences were limited to the warmer period, they were probably the result of active bacterial production and the concurrent consumption of freshly produced labile substrate.

Tab. 2. Genera and species of ciliates identified in LPS.

\begin{tabular}{l}
\hline Taxa \\
\hline Oligotrichida \\
Halteria grandinella \\
Pelagohalteria \\
Strombidium sp. \\
Strombidium viride \\
Prostomatida \\
Urotricha agilis \\
Urotricha furcata \\
Urotricha sp. \\
Holophrya sp. \\
Scuticociliatida \\
Cinetochilum margaritaceum \\
Ctedoctema \\
Cyclidium sp. \\
Histiobalantium \\
\hline
\end{tabular}

Tab. 3. Structure of microbial loop in ice-cover and icefree period in LPS from 1996 to 1998.

\begin{tabular}{lcclcc}
\hline & \multicolumn{2}{c}{ ice-free } & & \multicolumn{2}{c}{ ice cover } \\
\cline { 2 - 3 } \cline { 5 - 6 } & $\mu \mathrm{g} \mathrm{l}^{-1}$ & $\%$ & & $\mu \mathrm{g} \mathrm{l}^{-1}$ & $\%$ \\
\hline HPP & 21.7 & 78 & & 7.9 & 69 \\
HNF & 4.2 & 15 & & 3.1 & 27 \\
CIL & 2 & 7 & & 0.4 & 4 \\
\hline
\end{tabular}

\section{DISCUSSION}

During the three years, the TOC and the carbon calculated from microorganism biovolume revealed a different spatial and temporal distribution (Fig. 6). The TOC concentration gradient along the water column suggests a change with time of the mechanisms of DOC formation in the two layers. Phytoplanktonic EOC production, which can be as high as $37 \%$ of total carbon fixation (Callieri \& Bertoni, in prep.), could account for the DOC concentration rise in SUR and BOT after the ice-melt. The increase in DOC measured in December near the surface could be related to the presence of a sizeable phytoplankton population observed under the ice-cover (Pugnetti \& Bettinetti 1999, this issue). There is evidence in sea- and fresh-waters (Strom et al. 1997; Markager et al. 1994) of grazer-associated DOC release, higher than the DOC excreted by algae, which could support bacterial production. Although DOC production 
by macrozooplankton is not shown by our data, the late summer DOC rise, coinciding with a peak of Daphnia biomass (Manca \& Comoli 1999, this issue), might be the effect of intense grazing activity, particularly evident in September 97, near the bottom.

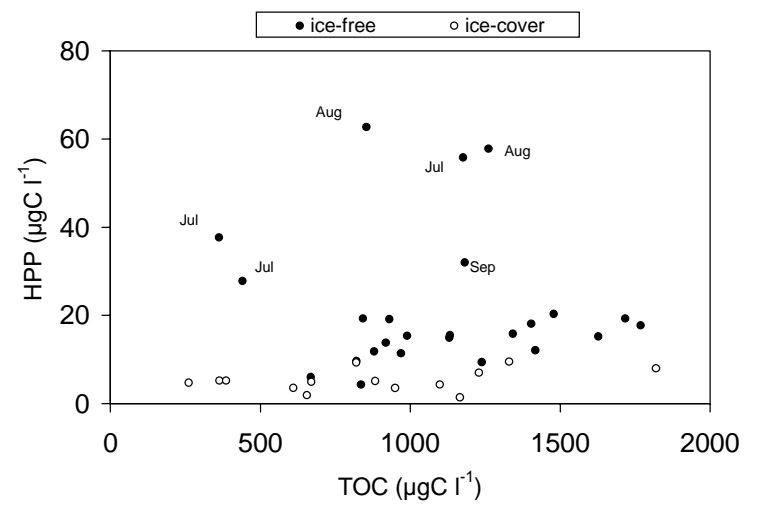

Fig. 5. Relation between TOC concentration and bacterial biomass $\left(\mu \mathrm{gC}^{-1}\right)$ with and without ice-cover in LPS.
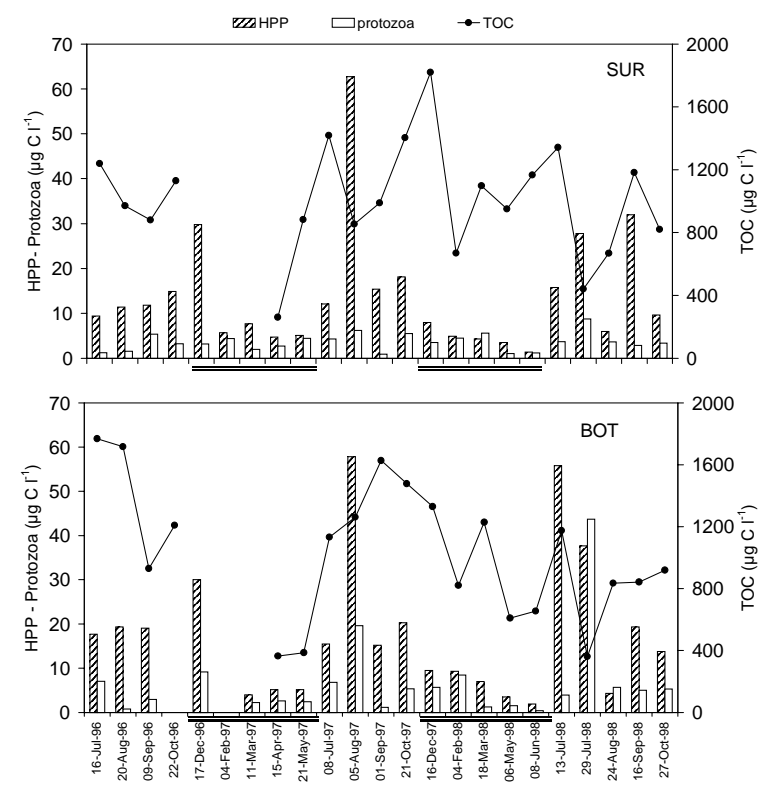

Fig. 6. Comparison of total organic carbon (TOC: $\mu \mathrm{gC} 1^{-1}$ ) with HPP-protozoa biomass $\left(\mu \mathrm{gC} \mathrm{l}^{-1}\right)$ calculated from microorganism biovolume at one meter below surface (SUR: upper panel) and at one meter above bottom (BOT: lower panel) in LPS.

With dynamics of this intensity, capable of producing in LPS a sevenfold TOC concentration change from one season to the other, it is clear that in this lake the DOC is made up mainly of molecules easily utilizable by bacteria. It is a situation quite different from that of the humic lakes of Northern Europe or North America, which have a high background concentration of DOC mainly made up of refractory humic substances (Kullberg et al. 1993). The labile DOC of LPS is probably not responsible for the low $\mathrm{pH}$ of the lake. Since the $80 \mathrm{~s}$ acidic precipitation, rich in sulfate, nitrate and ammonium has been affecting the $\mathrm{pH}$ of the water, which is characterized by low alkalinity (Mosello et al. 1993).

The particulate carbon of the micro-organisms of the microbial loop is $2 \%$ of TOC and increases to $3 \%$ if we include phytoplanktonic carbon in the estimate (data on phytoplankton from Pugnetti, pers. com.). The dynamics of this relatively negligible "active carbon" does, however, affect the seasonal variation of the dissolved carbon pool.

Bacteria are the main contributors to the carbon pool of the microbial food web. This is a characteristic of oligotrophic mountain clear-water lakes sensitive to acidification (Straškrabová \& Šimek 1993). The large rods and filamentous forms present in early summer disappear after the increase of Daphnia in the lake. In Lake Constance a shift in the bacterial community towards smaller forms and single cells was reported as an effect of cladoceran grazing (Güde 1988). HPP in LPS are able to triplicate their carbon in one month (see August 1997, BOT) and this is in accordance with the leucine and thymidine estimates of microbial activity (Callieri \& Bertoni, in prep.) from which around $1.4 \times 10^{6}$ cell $\mathrm{l}^{-1} \mathrm{~h}^{-1}$ were produced. In the oligotrophic LPS bacteria can outcompete phytoplankton and utilize the low P content, as has been demonstrated in laboratory experiments (Currie \& Kalff 1984). As a consequence, bacterial carbon in the ice-free period always exceeds phytoplankton carbon (Callieri et al. 1999, this issue). Winter temperatures are unfavorable for bacterial growth, so that their densities are very low under the ice-cover.

The low importance of the autotrophic component of picoplankton, in contrast with the expected increase of small cells in nutrient limited environments (Stockner 1991), could be the result of photoinhibition. The attenuation coefficient $(\mathrm{k}=0.22)$ was typical of a clearwater lake, so that the pelagic organisms have low protection from PAR and UV irradiation. Picocyanobacteria appeared to be vulnerable if irradiated by UVB in semi-natural conditions (Bertoni \& Callieri 1999).

Among protozoa, the heterotrophic nanoflagellates overtook the ciliates numerically also in 1996, when HNF appeared in low numbers. As regards biomass, an inverse significant correlation $(\mathrm{P}<0.05)$ between ciliates and HNF was found near the surface. This result is an indication of ciliate-flagellate interaction (Cleven 1996). During the ice-cover period, the presence of $\mathrm{HNF}>3$ $\mu \mathrm{m}$ coinciding with the mixotrophic peak (Pugnetti, pers. com) indicated that mixotrophic and heterotrophic species may occupy different niches. Studies on oligotrophic lakes (Berninger et al. 1992) showed that bacterivory by mixotrophs under the ice was not important. Under the ice-cover HNF may be the primary consumers of bacteria. Protozoa grazing activity measured in summer has shown that protozoa can exert an influence on the bacteria before the advent of Daphnia. The 
measurements of cell disappearance from protozoa grazing performed in LPS could explain a decrease of 4$20 \times 10^{6}$ bacteria $1^{-1} \mathrm{~h}^{-1}$, which is not negligible (Callieri $\&$ Bertoni, in prep.). In eutrophic and oligomesotrophic lakes the impact of protozoa on the bacterial population is 58 to $18 \times 10^{6}$ bacteria $1^{-1} \mathrm{~h}^{-1}$ in Rimov Reservoir and Lake Pavin, respectively (Šimek et al. 1997; Carrias et al. 1996).

Ciliate community structure showed a succession from Strombidium and Pelagohalteria, present in summer, to Urotricha sp. and Halteria grandinella, common under the ice-cover. The bacterivorous oligotrichs were found only in the summer period because of their strict dependence on food items which decreased in winter. Their decline in September has to be related to Daphnia grazing, as for the other organisms of the microbial food web. The ciliate population under the ice was composed by smaller individuals (like $U$. agilis) so that the resulting carbon biomass was very low (0.2-0.3 $\mu \mathrm{g} \mathrm{C} 1^{-1}$ at $\left.11 \mathrm{~m}\right)$. In Lake Redó similarly low ciliate carbon in winter was measured in the deepest part of the lake (Camarero \& Felip, pers. com.). Conversely, at $1 \mathrm{~m}$ in Lake Redó the ciliate carbon in winter was more than one order of magnitude higher than in LPS. This difference was mainly due to the absence of large mixotrophic ciliates in LPS during winter. In fact, Pelagohalteria and a mixotrophic Strombidium were only found in the ice-free period.

\section{CONCLUSIONS}

Few studies have analyzed the organic carbon and microbial assemblages in high mountain lakes for three successive years, including winter sampling under the ice. The present study is therefore unique, as we were able to assess the dynamics of the micro-organisms of the microbial food web of an extreme and simplified system. Lake Paione Superiore is oligotrophic (TN av. $400 \mu$ eq $\mathrm{l}^{-1}$; TP av. $2 \mu \mathrm{g} \mathrm{l}^{-1}$ ), acidic ( $\mathrm{pH}$ range: $5.5-6.3$ ) and has a maximum surface temperature of $14{ }^{\circ} \mathrm{C}$. In addition, fish are absent so that metazooplankton are not top-down controlled. Further limnological data have revealed the presence of a sizeable Daphnia population in late summer and of mixotrophic flagellates as the prevalent phytoplankton species, also under the icecover. The oligotrophic conditions of the lake might favor the processes of nutrient recycling in the microbial food web (Stockner \& Porter 1988), but the presence of a keystone species like Daphnia may influence the pathways of carbon flow in the microbial components, leading to more efficient transfer of carbon.

The evidence we gathered from our study suggests an effect of the ice-cover on the quantity and quality of the organisms present in the water column. The increase in TOC, occurring in July near the surface, enhanced the number of bacteria eventually utilizing this substrate. At this depth protozoa are never able to control HPP population. Near the bottom the dynamics is different, as protozoa can substantially affect the bacterial population, at least till August/September when Daphnia begins to increase. During July, August and September we monitored a rapid succession of: DOC production by phytoplankton, removal of bacteria by protozoan grazing, clearance of bacteria and protozoa by Daphnia and new DOC production by sloppy feeding of zooplankton. Near the bottom, during daylight, activity is enhanced and the resulting standing crops increased. We consider this lake to be a unique natural laboratory in which to study the relationships between the component of the microbial loop and Daphnia.

\section{ACKNOWLEDGMENTS}

This research was supported by the Commission of the European Community (project MOLAR ENV4CT95-0007). We wish to thank G. Tartari, A. Lami, A. Marchetto, M. Contesini for their work in the field and Viera Straškrabová for comments on the manuscript.

\section{REFERENCES}

Azam, F., T. Fenchel, J.G. Field, J.S. Gray, L.A. Meyer-Reil \& F. Thingstad. 1983. The ecological role of water-column microbes in the sea. Mar. Ecol. Prog. Ser., 10: 257263.

Berninger, U.G., D.A. Caron \& R.W. Sanders. 1992. Mixotrophic algae in the three ice-covered lakes of the Pocono Mountains, U.S.A. Freshwat. Biol., 28: 263-272.

Bertoni, R. 1978. Automatic determination of carbon and nitrogen in suspended matter of natural water with Carlo Erba 1106 CHN elemental analyzer. Mem. Ist. ital. Idrobiol., 36: 297-301.

Bertoni, R. \& C. Callieri. (1999). The role of UV-B radiation on freshwater autotrophic and heterotrophic picoplankton in a subalpine lake. J. Plankton Res., 21: 1373-1388.

Bertoni, R., C. Callieri \& A. Pugnetti. 1998. Dinamica del carbonio organico nel Lago di Cadagno e attività microbiche nel mixolimnio. Documenta Ist. ital. Idrobiol., 63: 105-120.

Bianchini, M. 1952. La Val Bognanco. Appunti di Geografia. Boll. soc. Geograf. Ital., ser. VIII: 118-135.

Blomqvist, P. 1996. Late summer phytoplankton responses to experimental manipulations of nutrients and grazing in unlimed and limed Lake Njupfatet, central Sweden. Arch Hydrobiol., 137: 425-455.

Callieri, C. \& R. Bertoni. (1999). Microbial assemblages and dissolved organic carbon in a simplified natural system: activity changes with and without Daphnia longispina: (in prep.).

Callieri, C., A. Pugnetti \& M. Manca. 1999. Carbon partitioning in the food web of a high mountain lake: from bacteria to zooplankton. In: Straškrabová, V., C. Callieri \& J Fott (Eds), Pelagic food web in mountain lakes. MOuntain LAkes Research Program. J. Limnol., 58(2): 144-151.

Cammarano, P. \& M. Manca. 1997. Studies on zooplankton in two acidified high mountain lakes in the Alps. Hydrobiologia, 356: 97-109.

Capblancq, J. \& H. Laville. 1983. Le lac de Port-Bielh (Pyrenees): exemple de fonctionnement d'une ecosysteme lacustre de haute montagne. In: M. Lamott \& F. Bourliere (Eds), Structure et fonctionnement des ecosystemes limnique. Masson: 51-79.

Carrias, J.F., C. Amblard \& G. Bourdier. 1996. Protistan bacterivory in an oligomesotrophic lake: importance of attached ciliates and flagellates. Microb. Ecol., 31: 249-268. 
Currie, D.J. \& J. Kalff. 1984. A comparison of the abilities of freshwater algae and bacteria to acquire and retain phosphorus. Limnol. Oceanogr., 29: 298-310.

de Bernardi, R., M. Brogi \& I. Origgi. 1983. Dinamica di popolazione e produzione di Arctodiaptomus alpinus in due laghi alpini d'alta quota: Laghi Boden, Alta Val Formazza, m 2340 s.l.m. Atti $5^{\circ}$ Congresso A.I.O.L.: 407-416.

Giussani, G., R. de Bernardi, R. Mosello, I. Origgi \& T. Ruffoni. 1986. Indagine limnologica sui laghi alpini d'alta quota. Documenta Ist. ital. Idrobiol,. 9: $415 \mathrm{pp}$.

Güde, H. 1988. Direct and indirect influences of crustacean zooplankton on bacterioplankton of Lake Constance. Hydrobiologia, 159: 63-73.

Guilizzoni, P., A. Marchetto, A. Lami, N.G. Cameron, P.G. Appleby, N.L. Rose, O.A. Schell, C.A. Belis, A. Giorgis \& L. Guzzi. 1996. The environmental history of a mountain lake (Lago Paione Superiore, Central Alps, Italy) for the last c. 100 years: a multidisciplinary, palaeolimnological study. J. Paleolimnol., 15: 245-264.

Komárek, J. 1996. Towards a combined approach for the taxonomic and species delimitation of picoplanktic cyanoprokaryotes. Algol. Studies, 83: 377-401.

Kullberg, A., K.H. Bishop, A. Argeby, M. Jansson \& R.C.Jr. Petersen. 1993. The ecological significance of dissolved organic carbon in acidified waters. Ambio, 22: 331-337.

Manca, M. \& P. Comoli. 1999. Studies on zooplankton of Lago Paione Superiore. In: Straškrabová, V., C. Callieri \& J Fott (Eds), Pelagic food web in mountain lakes. MOuntain LAkes Research Program. J. Limnol., 58(2): 131-135.

Markager, S., B. Hansen \& M. Søndergaard. 1994. Pelagic carbon metabolism in a eutrophic lake during a clear-water phase. J. Plankton Res., 16: 1247-1267.

McKnight, D.M., R. Harnish, R. L. Wershaw, J.S. Baron, \& S. Schiff. 1997. Chemical characteristics of particulate, colloidal, and dissolved organic material in Loch Vale Watershed, Rocky Mountain National Park. Biogeochemistry, 36: $99-124$

Mosello, R. 1984: Hydrochemistry of high altitude alpine lakes. Schweiz. Z. Hydrol., 46: 86-99.

Mosello, R. 1986. Effect of acid deposition on subalpine and alpine lakes in NW Italy. Mem. Ist. ital. Idrobiol., 44:117146.

Mosello, R., A. Marchetto, M.C. Brizzio, G.A. Tartari \& M. Rogora. 1999. Pluriannual evolution of the hydrochemistry of two Alpine lakes (Lake Paione Inferiore and Lake Paione Superiore, Ossola Valley) in relation to atmospheric loads. J. Limnol., 58(1): 42-48.

Mosello, R., A. Lami, P. Guilizzoni, M. Manca, A.M. Nocentini, A. Pugnetti, A. Boggero, A. Marchetto, G.A. Tartari, R. Bettinetti, M. Bonardi \& P. Cammarano. 1993. Limnological studies on two acid sensitive lakes in the Central Alps (Lakes Paione Superiore and Paione Inferiore, Italy). Mem. Ist. ital. Idrobiol., 51: 127-146.

Patrick, S., R.W. Battarbee, B. Wathne \& R. Psenner. 1998. Measuring and modelling the dynamic response of remote mountain lake ecosystems to envirnmental change: an introduction to the MOLAR project. In: S. Kovar, U. Tappeiner, N.E. Peters \& R.G. Craig (Eds), Hydrology, water resources and ecology in headwaters. Proceedings of the HeadWater'98 Conference, Merano. International Association of Hydrological Sciences Publ. No. 248, IAHS Press, Wallingford: 403-410.

Patterson, D.J. \& J. Larse. 1991. The biology of free-living heterotrophic flagellates. Clarendon Press, Oxford: 505 pp.

Pechlaner, R. 1971. Factors that control the production rate and biomass of phytoplankton in high-mountain lakes. Mitt. Internat. Verein. Limnol., 19: 123-145.

Psenner, R. 1989. Chemistry of high mountain lakes in siliceous catchments of the central eastern Alps. Aquat. Sci., 51: $108-128$.
Pugnetti, A. \& R. Bettinetti. 1995. The phytoplankton of two acid sensitive alpine lakes (lakes Paione, Central Alps, Italy). Mem. Ist. ital. Idrobiol., 53: 39-52.

Pugnetti, A. \& R. Bettinetti. 1999. Biomass and species structure of the phytoplankton of an high mountain lake (Lake Paione Superiore, Central Alps, Italy). In: Straškrabová, V., C. Callieri \& J Fott (Eds), Pelagic food web in mountain lakes. MOuntain LAkes Research Program. J. Limnol., 58(2): 127-130.

Ruggiu, D., R. Bertoni, C. Callieri, M. Manca \& A. M. Nocentini. 1998. Assesment of biota in lakes from the Khumbo Valley, High Himalayas. In: G. Tartari, R. Baudo \& M. Munavar (Eds), Top of the world environmental research. Ecovision World Monograph Series: 219-233.

Schindler, D.W. 1990. Experimental perturbations of the whole lakes as tests of hypotheses concerning ecosystem structure and function. Oikos, 57: 25-41.

Šimek, K., P. Hartman, J.Nedoma, J. Pernthaler, D. Springmann, J. Vrba \& R. Psenner. 1997. Community structure, picoplankton grazing and zooplankton control of heterotrophic nanoflagellates in a eutrophic reservoir during the summer phytoplankton maximum. Aquat. Microb. Ecol., 12: 49-63.

Sommaruga-Wögrath, S., R. Psenner \& R. Sommaruga. 1998. Dissolved organic carbon and chlorophyll concentrations in 52 high mountain lakes of the austrian alps: potential effects of climate warming. Verh. int. Ver. Limnol., 27: (in press).

Stockner J.G. 1991. Autotrophic picoplankton in freshwater ecosystems: the view from the summit. Int. Revue. ges. Hydrobiol., 76: 483-492.

Stockner, J.G. \& N.J.Antia. 1986. Algal picoplankton from marine and freshwater: a multidisciplinary perspective. Can. J. Fish. aquat. Sci., 43: 2472-2503.

Stockner J.G. \& K.G. Porter. 1988. Microbial food webs in freshwater planktonic ecosystems. In: S.R. Carpenter (Ed), Complex interactions in lake communities. Springer-Verlag, N.Y.:69-83.

Straškrabová, V., C. Callieri, P. Carrillo, L. Cruz-Pizarro, J. Fott, P. Hartman, M. Macek, J.M. Medina-Sánchez, J. Nedoma \& K. Šimek. 1999. Investigations on pelagic food webs in mountain lakes - aims and methods. In: Straškrabová, V., C. Callieri \& J Fott (Eds), Pelagic food web in mountain lakes. MOuntain LAkes Research Program. J. Limnol., 58(2): 77-87.

Straškrabová, V. \& K. Šimek. 1993. Microbial loop in lakes and reservoirs related to trophy and metazooplankton development. Verh. int. Ver. Limnol., 25: 1183-1186.

Strom, S.L., R. Benner, S. Ziegler \& M.J. Dagg. 1997. Plankton grazers are potentially important source of marine dissolved organic carbon. Limnol. Oceanogr., 42: 1364-1374.

The MOLAR Water Chemistry Group. 1999. The MOLAR Project: atmospheric deposition and lake water chemistry. In: Straškrabová, V., C. Callieri \& J Fott (Eds), Pelagic food web in mountain lakes. MOuntain LAkes Research Program. J. Limnol., 58(2): 88-106.

Tilzer, M., 1973. Diurnal periodicity in the phytoplankton assemblage of a high mountain lake. Limnol. Oceanogr., 18: 15-30.

Tilzer, M.M. \& K. Schwarz. 1976. Seasonal and vertical patterns of phytoplankton light adaptation in a high mountain lake. Arch. Hydrobiol., 77:488-504.

Tonolli, V. 1949. Gli alti laghi della Val Bognanco. Parte II. Mem. Ist. ital. Idrobiol., 5: 39-93.

Tonolli, V. 1954. Stabilità e produttività del limnobio alpino. Mem. Ist. ital. Idrobiol., 8: 29-70.

Wathne, B.M. 1992. Acidification of mountan lakes: paleolimnology and ecology. The AL:PE project. Documenta Ist. ital. Idrobiol., 32: 7-22. 